\title{
Genetic Control of Quantitative Variation in Carbonic Anhydrase Isozymes of Mammals. I. The Concentration Within Single Erythrocytes of the Mouse
}

\author{
Sun S. Hsu ${ }^{1}$ and Richard E. Tashian ${ }^{1}$ \\ Received 21 Jan. 1977_Final 18 Feb. 1977
}

The levels of the carbonic anhydrase isozymes ( $C A$ and $C A I I)$ in single erythrocytes of $D B A / 2 J$ mice were assayed by measuring the specific immunofuorescence of $C A$ I and $C A$ II with a microspectrofluorometric technique. Measurements of 100 randomly selected cells showed a range (in relative fluorescence

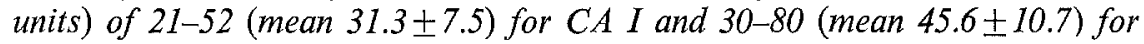
$C A$ II. The CA II/CA I ratio of the means obtained by the single-cell fluorescence assay was similar to the ratios obtained for the two isozymes from hemolysates of $D B A / 2 J$ mice using an immunodiffusion assay. The influence of cell age on the variation in carbonic anhydrase levels was determined by separating red cells into several fractions by a gravity sedimentation procedure. The younger cells showed higher levels of CA I and CA II than the older cells; however, the extensive overlap in the variability between the cells from the different fractions indicated that although cell age was contributing to the overall heterogeneity, its influence was not pronounced.

KEY WORDS: carbonic anhydrases I and II; mouse red cells; immunofluorescence; microspectrofluorometry.

\section{INTRODUCTION}

Carbonic anhydrase (EC 4.2.1.1. carbonate dehydratase) is present in mammals in at least two distinct molecular forms or isozymes, which have been

This investigation was supported by USPHS Grant GM 15419 and Training Grant 5-TO1GM-71-18 (S. S. H.).

${ }^{1}$ Department of Human Genetics, University of Michigan Medical School, Ann Arbor, Michigan. 
designated carbonic anhydrase I and II (CA I and CA II) ( $c f$. Tashian and Carter, 1976). The genes of these isozymes have been shown to be linked in the guinea pig (Carter, 1972) and pigtail macaque (DeSimone et al., 1973), and recently Eicher et al. (1976) have not only demonstrated that these two loci are closely linked in the mouse (Mus musculus) but have also shown that they are located on chromosome 3 near its centromere.

A considerable amount of information is now available concerning the comparative structures and activities of the two carbonic anhydrase isozymes ( $c f$. Lindskog et al., 1971); however, comparable data on the factors involved in the cellular control of these isozymes are still limited. Variations in the levels of CA I and CA II which appear to be under the control of both genetic and nongenetic factors ( $c f$. Tashian and Carter, 1976) have been observed in different tissues at both the evolutionary and developmental levels.

The present article describes a study of the quantitative variation in the levels of CA I and CA II in single erythrocytes of the mouse, Mus musculus, and represents part of our ongoing studies on the cellular regulation of CA I and CA II in mammalian cells.

Quantitation of CA I and CA II in the single erythrocytes of mouse peripheral blood was based on fluorescent antibody procedures (Kawamura, 1969; Levin et al., 1971; Sternberger, 1974). The resultant intensity of fluorescence from single erythrocytes was measured by the technique of microspectrofluorometry. The reliability of this technique is supported by the significant positive correlation found between the means of precipitin granule counts (cytoimmunodiffusion assay) or the relative immunofluorescence measurements (immunofluorescence assay) and the levels of CA I or CA II in hemolysates as measured by the radioimmunoassay (DeSimone et al., 1971; Magid et al., 1973; Bladon, 1976).

\section{MATERIALS AND METHODS}

The mice used in this study were from the inbred strain, DBA/2J, which were kindly provided by Dr. M. Foster, Mammalian Genetics Center, University of Michigan.

\section{Preparation of the Carbonic Anhydrase Isozymes and Primary Antisera}

Purified mouse CA I and CA II were isolated from pooled hemolysates by chromatography on a carboxymethyl cellulose (CM32) column equilibrated with $0.002 \mathrm{M}$, phosphate buffer, $p \mathrm{H}$ 6.6. After application of the hemolysate to the column, CA I and CA II, respectively, were eluted with a linear $0-0.2 \mathrm{M}$ $\mathrm{NaCl}$ gradient. Protein concentrations were determined by Lowry's method 
using obvine serum albumin (Sigma) as the standard. The purity of CA I and CA II was tested and confirmed by using starch gel electrophoresis (Tashian et al., 1968).

Unlabeled primary goat antisera against mouse CA I and CA II were prepared by Dr. R. H. Stern, Johns Hopkins University. These two antisera were absorbed by either purified mouse CA I or CA II $(50 \mu \mathrm{g} / \mathrm{ml})$. No crossreactivity was found between CA I and the CA II antisera or between CA II and the CA I antisera as determined by Ouchterlony-type double gel diffusion (Ouchterlony, 1968).

\section{Preparation of Secondary Antisera}

Rabbit anti-goat serum globulin antiserum conjugated with fluorescein isothiocyanate (FITC) was purchased from ICN Pharmaceuticals, Inc. The conjugate was shipped in lyophilic form and reconstituted by sterile distilled water as instructed by the supplier. The quality of the conjugate was checked by cellulose polyacetate electrophoresis in 3\% tris-barbital-sodium barbital buffer, ionic strength $0.09, p \mathrm{H} 8.8,150 \mathrm{~V}$, for $3 \mathrm{hr}$ at $4 \mathrm{C}$. After the strip was removed, it was examined under an ultraviolet (UV) transilluminator, and strong fluorescence was observed in the $\gamma$-globulin region.

Total protein concentrations were measured by the Biuret method with optical density readings at $560 \mathrm{~nm}$, and bovine serum albumin (Sigma) was used as a standard. The concentration of bound FITC was determined by the following equation (McKinney et al., 1964; Goldman, 1968):

$$
\text { bound FITC }(\mu \mathrm{g} / \mathrm{ml})=\frac{\text { free FITC standard }(\mu \mathrm{g} / \mathrm{ml}) \times \mathrm{OD}_{496} \text { conjugate }}{\text { OD }_{496} \text { FITC standard } \times 0.75}
$$

The F/P (fluorochrome to protein) ratio was found to be 2.40 . Evaluation of this conjugate by double gel diffusion against unlabeled primary mouse CA I or CA II antisera showed a clear, single fluorescent line of precipitation in the supporting Ouchterlony plate when viewed under UV light.

\section{Preparation of Blood Samples for Fixation and Staining}

Blood was drawn directly from the left ventricle of an anesthetized mouse. A $10-\mu \mathrm{l}$ aliquot was then washed three times in phosphate buffer saline (PBS),

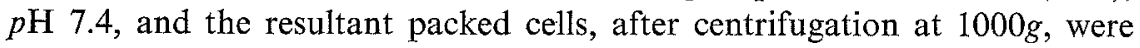
resuspended with appropriate dilution in PBS. These suspended erythrocytes were then ready for preparation of the blood smears.

Immunochemical staining of CA I and CA II was performed primarily on the basis of Coomb's method (Kawamura, 1969; Levin et al., 1971; 
Sternberger, 1974) in which unlabeled primary antibody is placed on the antigen and labeled secondary antibody is brought into contact with the antigen-primary antibody complex. Prior to the application of the stains, the blood smear prepared on the microscopic slide was fixed first by acetoneethanol (1:9) for $5 \mathrm{~min}$. Immediately after the fixative had evaporated, the slide was dipped into PBS for another $5 \mathrm{~min}$. After drying at room temperature, it was covered with an excess of the unlabeled primary goat antiserum diluted to a suitable concentration. The slide was then placed in a moist chamber and incubated at $37 \mathrm{C}$ for $30 \mathrm{~min}$.

Before application of the labeled secondary antiserum (rabbit antigoat globulin conjugated with FITC), the slide was rinsed gently with PBS twice. Immediately after drying, the slide was covered with the labeled secondary antiserum. After the slide was placed in a moist chamber and incubated at $37 \mathrm{C}$ for another $30 \mathrm{~min}$, it was rinsed with PBS twice and mounted with buffered glycerol, $p \mathrm{H}$ 8.5, for microscopic examination.

\section{Quantitation of CA I and CA II in Single Erythrocytes}

A Trinocular Fluorestar microscope (AO/H 20) equipped with a $100 \times$ dark phase contrast and a vertical illuminator of mercury vapor lamp (HBO50W) was used for the fluorescence determinations. The microscope was also equipped with all the filters necessary for scanning or measuring of the FITC fluorescence. An opaque metal disk was installed in the position of one of the excitation filters for blocking the source of UV light. Since the lifetime of the excited state of FITC is on the order of nanoseconds (Udenfriend, 1969), this installation made it possible to focus the microscopic field of view by dark phase contrast prior to exposure to the excitation wavelength. Similarly, another opaque metal disk was installed in the lower illuminator turret for blocking the bright light source from the 12-V tungsten-iodine lamp.

The Farrand microscope spectrum analyzer (MSA) system consisted primarily of the analyzer monochromator, the detector photomultiplier, the beamsplitter eyepiece, the photometer-amplifier, and the target spotter. The spotter is used to excite conjugated FITC within a single erythrocyte by means of a selected pinhole inserted in the monochromator. In other words, the intensity of fluorescence to be measured by this attachment is exactly the intensity of the selected area and is independent of the presence of the surrounding fluorescence. For measuring the fluorescent intensity of FITC from a single erythrocyte, the emission wavelength was set at $520 \mathrm{~nm}$ on the analyzer monochromator. The fluorescent intensity was enhanced by the photomultiplier and read directly on the photometer.

Immunochemical quantitation of the CA I and CA II isozymes from single erythrocytes was performed in a dark room. The UV light source was 
blocked by the opaque metal disk when the stained slide was examined under dark phase contrast. A single erythrocyte was then excited with the target spotter. At the start of the measurement, the bright light was obstructed by another opaque metal disk; simultaneously, the UV light and the photomultiplier were turned on. The fluorescence intensity units were then read immediately on the photometer. The fluorescence was measured in 100 erythrocytes selected at random by scanning the slide systematically from one end to the other.

The fluorescence standard was calibrated by a thin slice of polished uranium oxide glass imbedded in mounting material with a glass cover slip.

Photomicrographs were taken with Kodak Tri-X Pan film (ASA 400).

\section{Separation of Erythrocytes by Gravity Sedimentation}

Mouse peripheral erythrocytes were separated into a number of fractions by sedimentation at unit gravity using the method of Miller and Phillips (1969). The apparatus, STA-PUT, was obtained from Johns Scientific (Toronto, Canada).

Erythrocytes $\left(1.5 \times 10^{7}\right.$ cells $\left./ \mathrm{ml}\right)$ in PBS were fed using the cell buffer chamber to which $3 \%(\mathrm{v} / \mathrm{v})$ fetal calf serum in PBS had been added previously. In order to form the buffered step gradient (Miller and Phillips, 1969), $15-20 \mathrm{ml}$ of $5 \%(\mathrm{v} / \mathrm{v})$ of the fetal calf serum in PBS was then added to the cell buffer chamber. Two graduate gradient chambers were loaded with 600 $\mathrm{ml}$ of $15 \%(\mathrm{v} / \mathrm{v})$ and $30 \%(\mathrm{v} / \mathrm{v})$ fetal calf serum in PBS, respectively. When the flow was started, a gradient of fetal calf serum was generated which rose steeply from $5 \%$ to $15 \%$ and more slowly to $30 \%$. The cells were elevated to the top of this gradient and formed a band of cells in the cylindrical portion of the sedimentation chamber. After the solutions in two gradient chambers were emptied, the cells were allowed to settle for $4 \mathrm{hr}$. Then $200 \mathrm{ml}$ of the solution from the conical part of the sedimentation chamber at the completion of sedimentation was discarded, and the erythrocytes were collected into $4018-\mathrm{ml}$ fractions. All of the separation procedures were carried out at $4 \mathrm{C}$.

Erythrocytes in each fraction were centrifuged at $1000 \mathrm{~g}$ and washed twice in PBS. These cells were then used for immunochemical quantitation of single cells as described earlier. The number of red cells in each fraction was counted in a hemocytometer. Reticulocytes were stained with new methylene blue without fixation and counterstaining. The staining and counting methods were the same as those described by Brecher (1949).

\section{Controls}

Negative controls were used to establish the specificity of the fluorescence. 
After fixation, the control slide was covered with PBS instead of the unlabeled primary antisera. No fluorescence was found in the control slide. Occasionally, the controls were performed on the same slide divided into two sections, with one of the sections serving as the control.

\section{RESULTS}

\section{Concentration of CA I and CA II in Single Erythrocytes}

Photomicrographs of the immunochemical staining of CA I and CA II in mouse red cells are shown in Fig. 1. As can be seen, the intensity of the fluorescence varies from cell to cell. This intercellular heterogeneity was confirmed by actual fluorescence measurements employing the method of singlecell quantitation. The results obtained from the measurement of CA I and CA II in 100 cells are presented in the form of histograms in Fig. 2.

Although the intercellular heterogeneity of CA I and CA II fell into a different range of variation, their coefficients of variation (100 times the ratio of the standard deviation to the mean) were found to be similar. The CA II/CA I ratio of the means (1.42) obtained by the single-cell fluorescence assay was similar to the ratios of 1.12 and 1.92 obtained for the two isozymes from hemolysates of $\mathrm{DBA} / 2 \mathrm{~J}$ mice and $\mathrm{C} 57 \mathrm{BL} / 6 \mathrm{~J}$, respectively, using an immunodiffusion assay (Stern, 1975; Stern and Tashian, 1976).

\section{Effect of Red Cell Age on the Concentration of CA I and CA II}

Since there is substantial evidence that the activities of red cell enzymes change as red cells age in vivo (Berlin and Berk, 1975), it was important for the present study to determine to what extent the intercellular heterogeneity of CA I and CA II is a function of cell age.

The red cells that were used for this experiment were obtained from the same mouse that was used in the experiment described in the preceding section. The peripheral red cells of the mouse were separated according to age by the gravity sedimentation method. The rationale for this separation is based on the fact that older red cells are more dense than young red cells (Harris and Kellermeyer, 1970) and tend to sediment more rapidly in the gravity separation system.

When the number of cells was counted in each of the $4018-\mathrm{ml}$ fractions obtained after sedimentation, a rather symmetrical, bell-shaped distribution curve was obtained. Single-cell quantitation of CA I and CA II was carried out on 100 randomly selected cells from fractions $5,15,25$, and 35 . Since the older, denser cells sedimented more rapidly than the younger cells, the age order of the cells in the four fractions progressed from the first to the last 


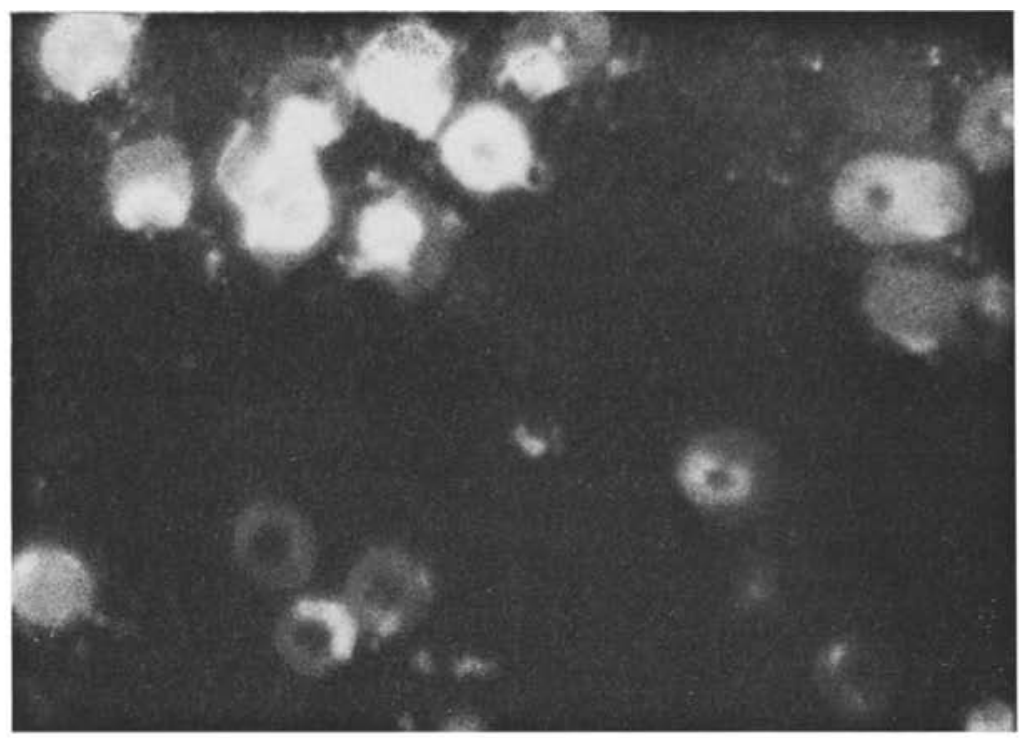

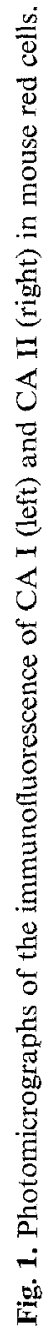

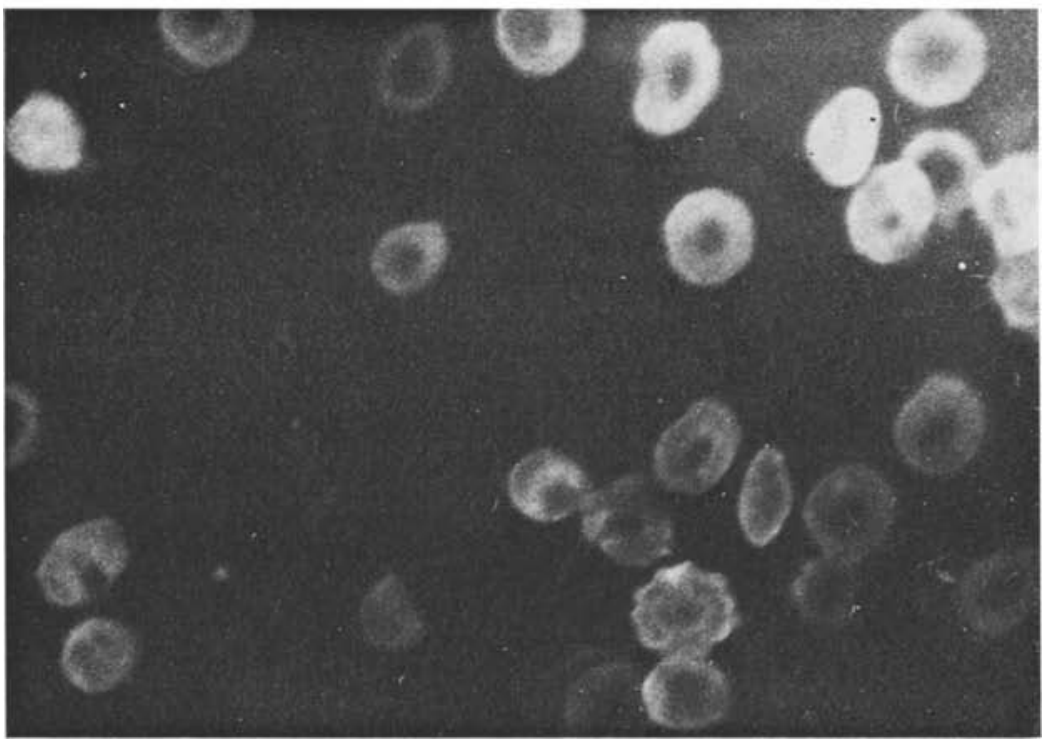




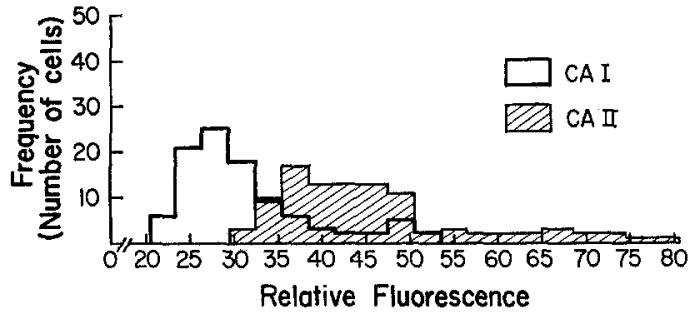

Fig. 2. Distribution of the relative fluorescence of $\mathrm{CA}$ I and CA II in mouse erythrocytes.

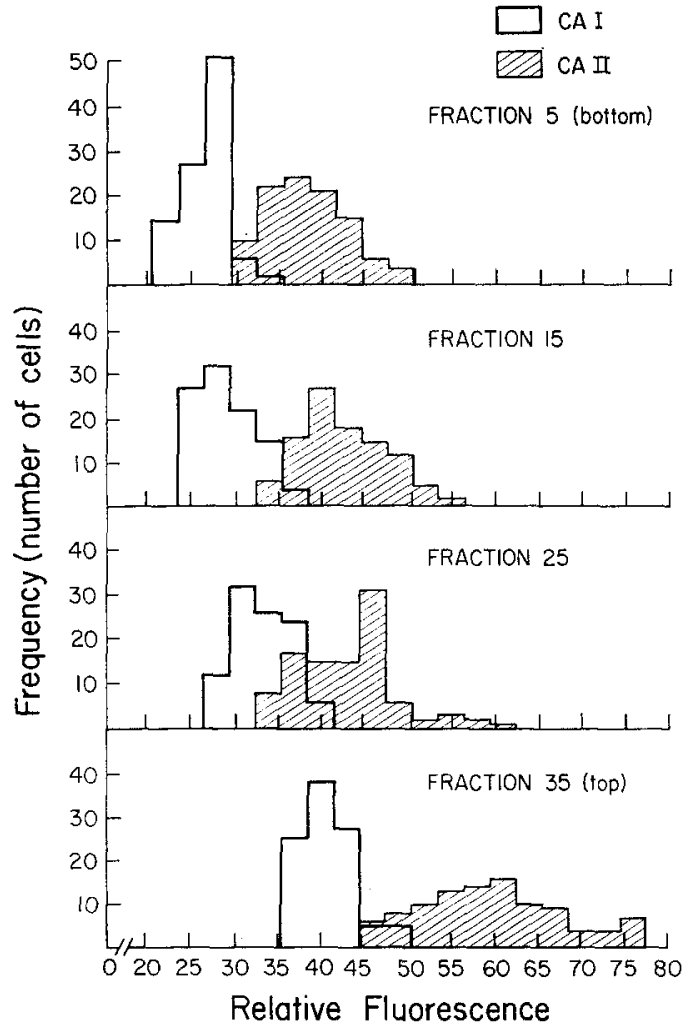

Fig. 3. Distribution of the relative fluorescence of CA I and CA II in mouse erythrocytes from the four fractions separated by gravity sedimentation.

fraction. Additional support for this age distribution of the cells is the fact that the reticulocyte count was observed to increase from the first to the last fraction (Table I). The percentage of reticulocytes in the unfractionated peripheral blood was found to be $1.7 \%$, which was within the normal range $(1-6 \%)$ reported for adult mice (Pinkerton and Bannerman, 1968). 
Table I. Immunofluorescent Quantitation of the Carbonic Anhydrase Isozymes in Single Mouse Erythrocytes from Unfractionated Peripheral Blood and Four Fractions Separated by Gravity Sedimentation

\begin{tabular}{|c|c|c|c|c|c|}
\hline \multirow[b]{2}{*}{$\begin{array}{l}\text { Source of } \\
\text { erythrocytes }\end{array}$} & \multirow[b]{2}{*}{$\begin{array}{c}\text { Reticulocytes } \\
(\%)\end{array}$} & \multirow[b]{2}{*}{ Isozymes } & \multicolumn{3}{|c|}{ Relative fluorescence } \\
\hline & & & $\begin{array}{c}\text { Ranges and } \\
\text { means }( \pm S E) \\
(n=100 \text { cells })\end{array}$ & $\begin{array}{l}\text { Coefficient } \\
\text { of variation } \\
(\mathrm{SE} / \text { mean })\end{array}$ & $\begin{array}{c}\text { Ratio of } \\
\text { CA II/CA I } \\
\text { (means) }\end{array}$ \\
\hline \multicolumn{6}{|l|}{ Unfractionated } \\
\hline \multirow[t]{2}{*}{ sample } & 1.7 & CA I & $21-52(31.3 \pm 7.5)$ & 0.238 & 1.46 \\
\hline & & CA II & $30-80(45.6 \pm 10.7)$ & 0.234 & \\
\hline \multirow[t]{2}{*}{ Fraction 5 (bottom) } & n) 0.0 & CA I & $21-33(26.8 \pm 2.3)$ & 0.087 & 1.42 \\
\hline & & CA II & $30-50(38.1 \pm 5.4)$ & 0.143 & \\
\hline \multirow[t]{2}{*}{ Fraction 15} & 0.0 & CA I & $2438(28.7 \pm 3.6)$ & 0.124 & 1.48 \\
\hline & & CA II & $33-56(42.6 \pm 4.9)$ & 0.116 & \\
\hline \multirow[t]{2}{*}{ Fraction 25} & 2.2 & CA I & $27-41(33.5 \pm 3.4)$ & 0.101 & 1.29 \\
\hline & & CA II & $34-60(43.1 \pm 5.6)$ & 0.130 & \\
\hline \multirow[t]{2}{*}{ Fraction 35 (top) } & 3.0 & $\mathrm{CA} \mathrm{I}$ & $36-50(40.9 \pm 3.2)$ & 0.078 & 1.46 \\
\hline & & CA II & $45-77(59.6 \pm 8.1)$ & 0.136 & \\
\hline
\end{tabular}

The results of the single-cell quantitation of CA I and CA II in the different fractions are shown in Fig. 3 and Table 1 . As can be seen, the mean fluorescence levels gradually increased from fraction 5 to 35 for both CA I and CA II, indicating that there was some reduction in the levels of CA I and CA II in the older red cells.

The coefficients of variation were determined for the intercellular variability of the fluorescence measurements for CA I and CA II (Table I). The coefficients of variation of CA I and CA II from the various fractions were found to be about one-half those found in the unfractionated control sample described in the previous experiment. This reduced variation seemed to be more pronounced for CA I than for CA II. In addition, the ratios of CA II to $\mathrm{CA} I$ in the different fractions were similar.

The CA I and CA II histogram peaks (Fig. 3) in fractions 5-25 were observed to shift slightly to the right, with a somewhat more pronounced shift for CA II than for CA I. However, in fraction 35, the CA I and CA II peaks exhibited a much more prominent shift to the right.

\section{DISCUSSION}

The finding of intercellular heterogeneity of the carbonic anhydrase isozyme levels in mouse erythrocytes was not unexpected since intercellular variation of CA I levels has been demonstrated in erythrocytes of the pigtail macaque using a cytoimmunodiffusion technique (DeSimone et al., 1971) and in 
human red cells with an immunofluorescence technique (Bladon, 1976). The question is, to what extent is this intercellular heterogeneity due to nongenetic factors such as technical artifacts or cell age.

When the mouse red cells are separated according to age, the intensity of the fluorescence is found to be lower in the cells from the fractions containing the older, denser cells and higher in the cells from the fractions containing the younger, less dense cells, with overlapping values indicating that although cell age is contributing to the observed heterogeneity its influence is not pronounced.

Fluorescent antibody techniques have been used to study the distribution of catalase in human red cells (Aebi and Suter, 1969) and lactate dehydrogenase in rat red cells (Poznakhirkina et al., 1975). The levels of these red cell enzymes appear to be fairly homogeneous throughout the red cell populations examined. It is also of interest that when fluorescent antibody studies were carried out on sheep red cells, which are known to contain only the CA II isozyme (Tanis and Tashian, 1971), little intercellular variability in fluorescence was observed (Bladon, 1976). It is possible that the heterogeneity observed in human and mouse red cells is a consequence of an interaction in the intracellular regulation of CA I and CA II.

The phenomenon of intercellular heterogeneity in the levels of a particular protein within single red cells has also been observed in the distribution of fetal hemoglobin ( $\mathrm{Hb} \mathrm{F}$ ) in red cells from adult humans. Using either immunological or alkali-denaturation studies, it has been shown that low levels of $\mathrm{Hb} \mathrm{F}$ are heterogeneously distributed in red cells from normal adult humans (Shepard et al., 1962; Dan and Hagiwara, 1967; Headings et al., 1975; Boyer et al., 1975). Heterogeneity in the levels of $\mathrm{Hb} \mathrm{F}$ in single erythrocytes has also been observed in individuals heterozygous for $\mathrm{Hb} \mathrm{S}$ (Stamatoyannopoulos et al., 1975; Wood et al., 1975). However, in individuals heterozygous for hereditary persistence of fetal hemoglobin (HPFH) of the African or Greek variety, all cells fluoresced after exposure to fluorescent antihemoglobin antibodies (Dan and Hagiwara, 1967; Wood et al., 1975).

Hansson (1965) has demonstrated by an immunological staining method that both CA I and CA II are present in the same human red cell. Although we have not measured the levels of CA I and CA II in the same cells, it is clear from the distribution of these two isozymes in the mouse red cell populations examined by us that both forms are present in the same cell. Thus the hypothesis stating that linked mammalian genes tend to be expressed in a mutually exclusive manner (Kabat, 1972) (i.e., the expression of one gene in a cluster of genes suppresses the expression of any other linked gene) does not seem to apply to the control of the carbonic anhydrase genes.

The basis for the intercellular heterogeneity of the carbonic anhydrase isozymes is obscure. It is possible that this variability derives from variation 
in carbonic anhydrase gene expression in early erythroid stem cells, and this problem is currently being studied in our laboratory by examining the levels of CA I and CA II in mouse erythroid clones in plasma clot cultures.

\section{ACKNOWLEDGMENTS}

We thank Dr. T. O. Sippel for his assistance with some of the technical aspects of this work. The excellent research assistance of Mrs. Ya-shiou L. Yu and Mrs. Sharon R. Stroup is gratefully acknowledged.

\section{REFERENCES}

Aebi, H., and Suter, H. (1969). Catalase. In Yunis, J. J. (ed.), Biochemical Methods in Red Cell Genetics, Academic Press, New York, pp. 255-288.

Anderson, N. G., Bahr, G. F., Bartels, P. H., Thorell, B., Tolles, W. E., and Wied, G. L. (1971). Chapter VIII: Patterns of cell populations. Acta Cytolog. 15, (5):444.

Berlin, N. L., and Berk, P. D. (1975). The biological life of the red cell. In Surgeon, D. M. (ed.), The Red Blood Cell, Vol. II, 2nd ed., Academic Press, New York.

Bladon, M. T. (1976). Studies on the quantitative variation of the levels of carbonic anhydrase in human sheep erythrocytes. Ph.D. dissertation, University of Michigan.

Boyer, S. H., Belding, T. K., Margolet, L., Noyes, A. N., Burke, P. J., and Bell, W. R. (1975). Variations in the frequency of fetal hemoglobin-bearing erythrocytes (F-cells) in well adults, pregnant women, and adult leukemics. Johns Hopkins Med.J. 137:105.

Brecher, G. (1949). New methylene blue as a reticulocyte stain. Am. J. Clin. Pathol. 19:895.

Carter, M. J. (1972). Carbonic anhydrase, isoenzymes, properties, distribution, and functional significance. Biol. Rev. 47: 465 .

Dan, M., and Hagiwara, A. (1967). Detection of two types of hemoglobin (Hb A and Hb F) in single erythrocytes by fluorescent antibody technique. Jap. J. Hum. Genet. 12(2):55.

DeSimone, J., Daufi, L. M., and Tashian, R. E. (1971). A semi-quantitation method for determining levels of carbonic anhydrase isozymes in individual red cells. Exp. Cell Res. 26:338.

DeSimone, J., Magid, E., and Tashian, R. E. (1973). Genetic variation in the carbonic anhydrase isozymes of macaque monkeys. II. Inheritance of red cell carbonic anhydrase levels in different carbonic anhydrase I genotypes of the pig-tailed macaque, Macaca nemestrina. Biochem. Genet. 8:165.

Eicher, E. M., Stern, R. H., Womack, J. E., Davisson, M. T., Roderick, T. H., and Reynolds, S. C. (1976). Evolution of mammalian carbonic anhydrase loci by tandem duplication close linkage of Car-1 and Car-2 to the centromere region of chromosome 3 of the mouse. Biochem. Genet. 14:651.

Goldman, M. (1968). Fluorescent Antibody Methods, Academic Press, New York.

Hansson, H. P. J. (1965). Demonstration of carbonic anhydrase by means of fluorescent antibodies in human erythrocytes. Life Sci. 4:965.

Harris, J. W., and Kellermeyer, R. W. (1970). The Red Cell, rev. ed., Harvard University Press, Cambridge, Mass.

Headings, V., Bhattacharya, S., Shukla, S., Anyaibe, S., Easton, L., Calvert, A., and Scott, R. (1975). Identification of specific hemoglobin within individual erythrocytes. Blood 45,2:263.

Kabat, D. (1972). Gene selection in hemoglobin and in antibody-synthesizing cells. Science 175:134.

Kawamura, A. J. (ed.) (1969). Fluorescent Antibody Techniques and Their Applications, University Park Press, Baltimore. 
Levin, A., Killander, D., Klein, E., Nordenskjold, B., and Inoue, M. (1971). Applications of microspectrofluorometry in quantitation of immunofluorescence on single cells. Ann. N.Y. Acad. Sci. 177:481.

Lindskog, S., Henderson, L. E., Kannan, K. K., Liljas, A., Nyman, P. O., and Strandberg, B. (1971). Carbonic anhydrase. In Boyer, P. D. (ed.), The Enzymes, Vol. V, Academic Press, New York, pp. 587-665.

Magid, E., DeSimone, J., and Tashian, R. E. (1973). Genetic variation in the carbonic anhydrase isozymes of macaque monkeys. $\mathrm{I}$. The radioimmunosorbent assay. Biochem. Genet. 7:157.

McKinney, R. M., Spillane, J. T., and Pearce, G. W. (1964). Factors affecting the rate of reaction of fluorescein isothiocyanate with serum proteins. Anal. Biochem. 9:474.

Miller, R. G., and Phillips, R. A. (1969). Separation of cells by velocity sedimentation. $J$. Cell. Physiol. 73:191.

Ouchterlony, O. (1968). Handbook of Immunodiffusion and Immunoelectrophoresis, Ann Arbor Science Publishers, Ann Arbor, Mich.

Pinkerton, P. H., and Bannerman, R. M. (1968). The hereditary anemias of mice. Hematol. Rev. 1:119.

Poznakhirkina, N. A., Serov, O. L., and Korochkin, L. I. (1975). A study on lactate dehydrogenase isozymes in rat ova. Biochem. Genet. 13:65.

Shepard, M., Weatherall, D., and Conley, C. (1962). Semi-quantitative estimation of the distribution of fetal hemoglobin in red cell populations. Bull. Johns Hopkins Hosp. 110:293.

Stamatoyannopoulos, G., Wood, W. G., Papayannopoulou, T., and Nute, P. E. (1975). A new form of hereditary persistence of fetal hemoglobin in blacks and its association with sickle cell trait. Blood 46:683.

Stern, R. (1975). Biochemical genetics of mouse carbonic anhydrases and hemoglobins. Ph.D. dissertation, Johns Hopkins University.

Stern, R., and Tashian, R. E. (1976). Thyroid status and carbonic anhydrase levels in mouse erythrocytes. Proc. Soc. Exp. Biol. Med. 153:143.

Sternberger, L. A. (1974). Immunocytochemistry, Prentice-Hall, Englewood Cliffs, N.J.

Tanis, R. J., and Tashian, R. E. (1971). Purification and properties of carbonic anhydrase from sheep erythrocytes, Biochemistry 10:4852.

Tashian, R. E., Shreffler, D. C., and Shows, T. B. (1968). Genetic and phylogenetic variation in the different molecular forms of mammalian erythrocyte carbonic anhydrases. Ann. N.Y. Acad. Sci. 151:64.

Tashian, R. E., and Carter, N. D. (1976). Biochemical genetics of carbonic anhydrase. In Harris, H., and Hirschhorn, K. (eds.), Advances in Human Genetics, Vol. 7, Plenum Press, New York, pp. 1-56.

Udenfriend, S. (1969). Fluorescence Assay in Biology and Medicine, Vol. II, Academic Press, New York.

Wood, W. G., Stamatoyannopoulos, G., Lim, G., and Nute, P. E. (1975). F-cells in the adult: Normal values and levels in individuals with hereditary and acquired elevations of $\mathrm{Hb} \mathrm{F}$. Blood 46:671. 